А. ЛЯШЕВА

\title{
ЖИлИщНЫЙ БУМ \\ В ПОСТКРИЗИСНОМ КИЕВЕ: РОСТ БЕЗ ФИНАНСОВ
}

Алена Ляшева, PhD, старший преподаватель кафедры социологии Украинского католического университета (Львов), исследователь в постдокторантуре Центра исследования Восточной Европы Университета Бремена, редактор журнала социальной критики «Спільне»; Украина, 79000, Львов, ул. Иллариона Свенцицкого, д. 17, офис 307.

E-mail: liasheva.a@ucu.edu.ua

Во многих городах по всему миру финансиализация жилья привела к социальным и пространственным изменениям. Сценарий этого процесса был в общих чертах схож: массивное вливание финансового капитала в недвижимость провоцировало строительный бум, что среди прочих причин привело к глобальному финансовому кризису 2008 года. После кризиса система финансирования строительства была во многих странах восстановлена. Этого удалось добиться даже периферийным городам Европы - часто за счет государственных программ финансирования ипотеки, примером чего являются Венгрия и Россия. Но в Украине кардинально иная ситуация: жилищный рынок не получил ни государственной поддержки, ни внешних вливаний капитала, но тем не менее продолжает функционировать. Последние пять лет в больших городах наблюдается активное строительство, и лишь недавно стали проявляться признаки нового падения, когда две крупные строительные компании Киева «заморозили» свои проекты. Чтобы разобраться с этим противоречием, мы попытаемся ответить на следующий исследовательский вопрос: каким образом в украинских городах продолжался жилищный рост в 2015-2019 годах, несмотря на отсутствие существенных инвестиций в кредитование недвижимости? Предлагаемое объяснение состоит в том, что жилищный рост вызван высокой разницей в уровне собственности и доходов украинцев, увеличившейся ввиду периферизации украинской экономики за последние пять лет, а также возникновением нового механизма накопления, в большей мере замкнутого внутри страны. Эта гипотеза будет подтверждена следующим образом. Во-первых, мы систематизируем существующие исследования финансиализации жилья, акцентируя внимание на разнице между центром и периферией. Во-вторых, проанализируем режим финансирования жилищной сферы, характерный для вышеуказанного кейса, на основе количественных данных, демонстрирующих разрыв международной цепочки финансиализации жилья, а также на основе качественных данных, объясняющих социальные и политические механизмы этого процесса. В-третьих, будут описаны социальные риски сложившейся ситуации и показана связь между периферийной позицией Украины в глобальной экономике и установившимся в последние годы механизмом жилищного финансирования.

Ключевые слова: жилье; финансиализация; Киев; периферийный капитализм; постсоветские города

Цитирование: Ляшева А. (2019) Жилищный в бум в посткризисном Киеве: рост без финансов//Городские исследования и практики. Т. 4. № 3. С. 60-70. DOI: https://doi.org/10.17323/usp43201960-70

\section{Вступление}

$\Phi$ инансиализация жилья стала глобальным трендом в последние десятилетия. Особенное внимание в академической среде этот процесс получил после 2008 года, когда последствия его было сложно не заметить даже тем, кто не был напрямую вовлечен в сферу недвижимости, - ведь именно «жилищный пузырь» стал ассоциироваться с глобальным финансовым кризисом [Kamin, DeMarco, 2012; Martin, 2011]. Концептуализация механизмов финансиализации жилья в первую очередь была проведена на эмпирическом материале западных городов и стран [Aalbers, 2008], и лишь затем исследователи проанализировали отличия между странами ядра и периферии. Этот анализ воплотился в концепте (полу-)периферийной либо зависимой финансиализации [Bohle, 2018]. Такое разграничение финансиализации жилья подчеркивает, что в странах периферийного капитализма глобальные процессы воплощаются иначе (иногда радикально иначе), чем в странах ядра, но процессы и там и там являются 
частями целого. В этой статье мы сделаем попытку раскрыть данный механизм, описав ситуацию в Киеве и в Украине после 2014 года. Мы попробуем показать, как ряд факторов привел к тому, что за последние пять лет, начиная с критического снижения курса гривны в марте 2014 года, сфера недвижимости развивалась, несмотря на отсутствие доступной ипотеки, что отличает Украину от соседних (полу-)периферийных стран. Хотя это сравнение будет построено на отличиях, оно верифицирует утверждение о зависимой природе финансовых потоков между разными регионами мира.

В первом разделе мы проанализируем предмет финансиализации жилья, опираясь на работы географов и социологов, изучавших как страны центра, так и периферии. Во втором - представим исследовательские вопросы и кратко изложим методологию нашего исследования. В третьем - рассмотрим механизмы финансиализации жилья и их связь с периферизацией украинской экономики.

\section{Финансиализация между центром и периферией}

Понятие финансиализации получило довольно широкое распространение в среде критических географов, социологов и экономистов. Разные исследования рассматривают различные аспекты финансиализации, но является консенсусом то, что этот процесс подразумевает рост влияния финансовых акторов и механизмов в общественных сферах, ранее с финансовой сферой не связанных или связанных слабо [Epstein, 2005]. Одним из самых распространенных является определение Криппнер: «Модель накопления, при которой получение прибыли все чаще происходит через финансовые каналы, а не через торговлю и товарное производство» [Krippner, 2004]. Из этого определения можно выделить следующие важные характеристики процесса финансиализации: во-первых, накопление капитала рассматривается как ключевая причина развития процесса финансиализации. Во-вторых, финансиализация возникает как альтернатива «классическим», продуктивным механизмам получения прибыли - производству товара и торговле. В-третьих, понятие финансиализации описывает рост тренда, а не стабильную ситуацию, поэтому исследование финансиализации должно быть чувствительно к временным рамкам.

Какое отношение имеет финансиализация к жилью? Наиболее полный ответ на этот вопрос представлен в книге под редакцией Альберса - «Финансиализация жилья. Политэкономический подход». Авторы рассматривают изменения в функционировании рынков недвижимости, вызванные ростом вклада ипотечного кредитования. Красной линией проходит идея о том, что жилье становится не домом и даже не товаром, а звеном в процессе перетекания капитала от домохозяйств к банкам через ипотечные займы. Этот процесс возможен благодаря экспансии ипотечных рынков. Одним из ключевых механизмов этой экспансии в западных экономиках стало расширение вторичного рынка ипотек посредством секьюритизации, то есть выпуска ценных бумаг, подкрепленных портфелями ипотечных кредитов. Такой финансовый механизм обеспечивал ликвидность рынка недвижимости и делал возможным жилищный бум. Жилья становилось все больше, но одновременно росли и цены на жилье, ведь ипотека была доступной и повышала эффективный спрос. В 2008 году такая схема достигла предела, так как вернуть займы стало невозможно. Однако со временем она возобновила свое функционирование во многих западных странах, но уже зачастую с участием государственного капитала [Aalbers, 2016].

Каким образом финансиализация жилья воспроизводит и углубляет зависимость центра и периферии? Для начала дадим актуальное для этой статьи определение данной зависимости. Хотя классики центр-периферийного подхода определяли центр и периферию, очерчивая конкретные регионы глобальной системы [Wallerstein, 2004], мы ориентируемся на парадигму, рассматривающую глобальные зависимости как проявление неравномерного географического развития. Подчеркивая наличие зависимостей не только между глобальными регионами (глобальный север/глобальный юг), но и между регионами в одной стране, районами в одном городе и т. д. [Smith, 2008]. Такой подход подчеркивает гибкость и многоуровневость зависимости, при этом не отрицая основного его признака: извлечения стоимости акторами, находящимися в одном пространстве, из другого пространства [Arrighi, 1994], будь это страна, область или район. Для конкретизации такого подхода представляется уместным рассматривать линии зависимости через призму глобальных сетей, окутывающих современный мир [Urry, 
2007]. Тогда центр-периферийная зависимость оказывается комплексом социальных сетей, связывающих страны, области, города и районы отношениями извлечения стоимости, воспроизводя социально-пространственные неравенства. Роль финансиализации в этом процессе была рассмотрена Соколом [Sokol, 2017]. Он вводит понятие «финансовые цепочки», которое подразумевает и «каналы перемещения стоимости (между людьми и местами)», и «социальные отношения, формирующие социально-экономические отношения и сопутствующие им экономические географии» [Sokol, 2017]. Именно такие цепочки формируются в процессе финансиализации жилья и приводят к разным механизмам и последствиям финансиализации в центре и на периферии.

Чем же эти процессы отличаются в центре и на периферии? Для ответа на этот вопрос стоит спуститься на уровень акторов и механизмов, а также подробнее рассмотреть последствия, анализируя сходства между разными странами.

Самым явным показателем периферийной финансиализации жилья является роль иностранного капитала в той или иной стране. В Венгрии филиалы западноевропейских банков начали появляться уже в 1990-х годах, это явилось основным каналом финансиализации с начала 2000-х, когда ипотечные кредиты стали предлагаться под низкий процент в иностранной валюте [Ро́s$f a i, 2018]$ и их доступность выросла. В России основным источником финансирования ипотеки и других кредитов были доходы от торговли нефтью [Büdenbender, Lagna, 2019]. На Украине же действовали оба механизма. С одной стороны, банки, являющиеся частью финансово-промышленных групп, направляли доходы на рынок ипотеки, с другой - они же брали займы у западных банков и кредитовали украинские домохозяйства, повышая процентную ставку. Позже, в последние годы перед кризисом, на бушующий украинский рынок пришли напрямую и западные банки. Таким образом, «входы» иностранного капитала на ипотечные рынки Восточной Европы могли быть разными, в зависимости не только от странового контекста, но и от временного этапа, но логика глобального накопления капитала присутствовала везде.

Помимо этого, общим для периферийных стран было сотрудничество международных и местных элит. Начиная с 1990-х годов как в России, так и в Венгрии принимались законы, сделавшие возможным приток иностранного капитала [Pósfai, Nagy, 2017; Büdenbender, Lagna, 2019]. В Украине аналогичные меры были приняты намного позже - в середине 2000-х, когда иностранные финансовые потоки уже стали данностью. Не имея возможности конкурировать с западными финансовыми акторами, местные элиты использовали интерес иностранного капитала к Восточной Европе как возможность получить и экономические, и политические выгоды. Последние формировались ввиду того, что доступность потребительских кредитов представлялась как прогресс экономики, а значит, и верное управление страной.

Другой особенностью периферийной финансиализации жилья является нетипичность механизмов данного процесса. Являясь ключевым механизмом получения ликвидности в западных экономиках в периферийных контекстах, секьюритизация часто отыгрывала и другую роль. Поскольку в Украине отсутствовали легальные возможности для секьюритизации, ликвидность обеспечивалась посредством относительной изолированности украинского финансового рынка. Украинская макроэкономическая среда с высокой инфляцией и фактической привязкой курса гривны к доллару США, установленной Национальным банком Украины (НБУ), обещала высокие риски, но и высокую норму прибыли. Это давало возможность брать кредиты на западных рынках под низкую ставку, а затем кредитовать в Украине под более высокую, которая все равно была ниже, чем до бума 2000-2008 годов. Эти спекуляции повышали ликвидность рынка жилья, делая секьюритизацию неактуальным и бюрократически сложным процессом.

После кризиса еще одной особенностью периферийной финансиализации стала роль государства. Во многих странах именно государственные институты после кризиса взяли на себя доминирующую роль в сфере финансов и недвижимости, что позволило административному аппарату усилить вертикаль власти. Именно это произошло в России и Венгрии [Pósfai, Gál, Nagy, 2017; Büdenbender, Lagna, 2019]. В Украине же после кризиса 2008 года государственным акторам удалось лишь частично справиться с его последствиями, получив кредитование от МВФ. В период с 2008 по 2010 год был получен самый большой в истории Украины заем от МВФ - 14,4 млрд евро, что сделало страну одним из самых крупных его должников [Кравчук, 2015; Milesi-Ferretti, Tille, 2011]. Но после кризиса 2015 года государственное вмешательство в сферу недвижимости практически прекратилась. При этом в больших городах в период с 2015 по 2019 год шло бурное строительство жилья. 
Подводя итоги, отметим, что страны Восточной Европы получили отличный от западного опыт финансиализации жилья, поскольку местный финансовый рынок как в плане капитала, так и в плане институциональности ипотечной системы не мог конкурировать с международными банками. В то же время местные политические элиты могли регулировать и извлекать выгоду, паразитируя на потоках капиталов между центром и периферией.

Важно заметить, что воспроизвести бум жилищного и ипотечного рынка в регионе невозможно в других сферах. Недвижимость хотя и является важной сферой для конструирования глобальных финансовых зависимостей, не способна отображать экспортно-импортные связи или миграционные потоки. Также не стоит экстраполировать особенности Восточной Европы, которая выступает главным кейсом этой статьи, на другие периферии.

Очертив связи между периферийностью и финансиализацией жилья, мы попытаемся показать, каким образом кейс Киева последних лет, отличаясь от общей тенденции, может улучшить понимание этих цепочек. Но сначала рассмотрим методологию.

\section{Методология исследования}

Эта статья развивает наработки кандидатской диссертации (PhD) автора, посвященной теме финансирования, производства и распределения жилья в постсоветском Киеве, в которой анализируется становление и трансформация рынка жилья на постсоветском пространстве на примере самого большого города Украины. Главный исследовательский вопрос этой статьи звучит следующим образом: каким образом в украинских городах продолжался жилищный рост в 2015-2019 годах, несмотря на отсутствие значимых финансовых потоков в кредитовании недвижимости? Имеет смысл разложить его на ряд более конкретных вопросов:

1. Каким образом изменилась ситуация на рынке жилья больших украинских городов в 2015-2019 годах?

2. Какие механизмы финансирования преобладали в этот период по сравнению с предыдущими и по сравнению с другими городами Восточной Европы?

3. акие социальные группы вовлечены в этот процесс и почему?

4. Каким образом эти механизмы связаны с реструктуризацией украинской экономики и местом Украины в глобальных сетях центр-периферийной зависимости?

Ответ на первый вопрос дан посредством анализа статистических данных украинского рынка жилья за последнее десятилетие, собранных из государственных и частных баз статистики. Основными индикаторами тут выступают интенсивность застройки, цены на рынке куплипродажи жилья, объем ипотеки и ипотечного долга населения.

Для ответа на второй и третий вопросы мы проанализировали глубинные интервью с акторами сферы жилья. Среди них чиновники городских органов власти Киева, сотрудники строительных компаний, члены организаций, объединяющих банки, риелторы, архитекторы, журналисты и активисты, покупатели квартир, а также другие люди, чьи интересы и деятельность тем или иным образом касаются жилищной сферы. Основной темой интервью являлся личный опыт респондента, связанный с жилищной сферой во временной перспективе, то есть вопрос был про изменения сферы жилья с 1990-х годов и по сегодняшнее время. Таким образом, была получена вариация опытов «столкновения» с жилищной сферой. Всего между мартом 2017 и сентябрем 2018 года было собрано более 50 интервью. Этот метод был скомбинирован с анализом документов - законодательства и презентаций акторов в СМИ, а также с наблюдением на мероприятиях. И для третьего, теоретического, вопроса было проведено сравнение с другими странами Восточной Европы.

Такой подход, основанный на количественной и качественной методологии, позволил проанализировать не только легальные и формальные, но и неформальные механизмы производства и финансирования жилья, а также понять интерес акторов в этих процессах. А сравнительный подход поместил кейс Киева в глобальный контекст.

\section{Финансируя жилищный рост без ипотеки}

После массовых протестов 2014 года, аннексии Крыма и вооруженного конфликта на востоке Украины новая волна экономического кризиса накрыла украинскую экономику. Это сильно отразилось на рынке жилья. В первую очередь драматическим падением цен на квартиры. 
По данным портала о недвижимости «Домик», средняя цена квадратного метра в квартирах Киева с марта 2014 по апрель 2015 года упала с 1700 до 1240 долл., что составило 73\%. После этого в период 2015-2020 годов средняя цена варьировалась на уровне 2015 года, максимально снижаясь всего на 16\% [Цены на недвижимость..., 2020]. Очевидно, что такой спад был вызван в первую очередь падением курса гривны. По курсу НБУ с весны 2014 по весну 2015 года гривна обесценилась в три раза и лишь немного восстановилась с тех пор [Офіційний курс..., 2020]. Таким образом, падение цен в долларах фактически стало их повышением для потребителей с гривневым доходом. Ниже, при анализе качественных данных, мы подробнее рассмотрим, каким образом эти изменения повлияли на доступность жилья для украинцев.

Кроме рынка купли-продажи кризис затронул и ипотечный рынок. Хотя данные про объем и число сделок довольно фрагментарны, общие тенденции проследить можно. По данным НБУ, после кризиса 2008 года объем ипотечных займов резко снизился - на 66\% с 2008 по 2012 год [Статистика..., 2020]. Это было вызвано значительным оттоком иностранного капитала с рынка кредитования. Последние восемь лет ипотечный рынок функционирует в основном в гривне, не получая существенных вливаний извне. На слабость, если не безжизненность этой сферы указывает Министерство юстиции Украины. Хотя с 2015 по 2019 год количество договоров ипотеки квартир и жилых домов увеличилось в два раза, число оформленных ипотечных кредитов в 2019 году составило 13507 [Звіт про роботу..., 2020], что, конечно же, совсем немного для страны с четырьмя городами-миллионниками.

Ни иностранные, ни местные банки ввиду высоких рисков невозврата не готовы кредитовать украинскую ипотечную систему под низкие проценты. В 2017 году индикатор NPL (non-performing loans) составлял 58\% - это глобальный исторический максимум на данный момент, к началу 2020 года данный индикатор снизился до 48,4\%, но это все равно очень высокий уровень [Звіт про фінансову..., 2019; Звіт про фінансову.., 2019]. Банки не прекращают предоставлять ссуды, но их основной фокус - небольшие кредиты: менее рискованные, чем ипотечные, так называемое микрокредитование. Например, финансиализируется реновация жилищной недвижимости. В качестве ответа на рост цен на коммунальные услуги государство предлагает собственникам ремонтировать жилье, используя энергосберегающие технологии, и выдает «теплые кредиты» от двух государственных банков. И хотя улучшение качества жилья - очень важная задача, она реализуется посредством весьма рискованного механизма.

Как же такие изменения финансовой сферы повлияли на интенсивность жилищного строительства? Она не только не упала, но и продолжила расти, причем скачок произошел в 2014 году - на 12,5\% по сравнению с предыдущим годом. После 2017 года происходит спад, но не интенсивный [Державна служба..., 2020]. Это стало возможным благодаря альтернативным способам финансирования на фоне слабой ипотечной системы.

Во-первых, жилье финансируется за счет депозитов из обанкротившихся банков. Когда все больше банков в 2014 году начали испытывать трудности, люди бросились забирать свои сбережения. Способом обезопасить деньги стали инвестиции в недвижимость. Эта тенденция присутствовала и раньше, но усилилась после 2014 года. Во-вторых, застройщики стали предлагать рассрочку на четыре-пять лет, что превращает их самих в финансовые учреждения. В-третьих, банки по-прежнему предлагают ипотеку, но лишь небольшое число потребителей готово платить первые и процентные взносы по ставке 15-25\%. В-четвертых, менее состоятельные покупатели жилья используют свои социальные связи - типичной является ситуация одалживания у широкого круга родственников и знакомых. В-пятых, работники сфер, интегрированных в глобальную экономику, например, ИТ, продолжают быть потенциальными покупателями жилья. Часто маркетинг жилищных комплексов ориентирован только на них: возникают так называемые ИТ-кластеры - районы, в которых застройщик в сотрудничестве с ИТ-компаниями предлагает жилье сотрудникам этих компаний. Такой механизм должен обезопасить застройщика, но приводит к кричащей социально-пространственной сегрегации [Львівський IT Кластер, 2020]. Наконец, жилье бизнес-класса часто покупают иностранцы, которых привлекают низкие цены. Таким образом, подобное приобретение доступно немногим и часто рассматривается как надежная инвестиция в условиях нестабильной экономики. Описанный процесс можно охарактеризовать как активизацию (assetisation) без финансиализации [Ward, Swyngedouw, 2018].

Можно выделить следующие последствия таких изменений. Доступность жилья ограничивается несколькими социальными группами [Федорів, Ломоносова, 2019]. Часть составляют 
работники среднего и высшего звена иностранных компаний, среди которых выделяются работники ИТ-сферы. Следующая группа - трудовые мигранты, для которых инвестиция в квадратные метры является относительно надежным способом накопления. Такие финансовые потоки заметно стимулируют строительство в западных областях страны, например в ИваноФранковске [Лящева, 2019], в отличие от других регионов. Еще одной группой покупателей является отечественная и иностранная элиты. Такие потребители могут, как правило, позволить себе покупку без рассрочки. Как прозвучало в одном интервью сотрудника ориентирующейся на премиум-сегмент рынка компании-застройщика:

Из 220-250 квартир только четыре покупаются в рассрочку, большинство потребителей сразу платят всю цену, 2-3 млн гривен [70 000-110 000 евро]. Таким образом, вы понимаете, каков уровень клиентов.

Также есть много клиентов из Турции, Израиля, Японии, Азербайджана и других стран. В основном они приобретают жилье через украинских агентов по недвижимости, которые играют, скорее, роль финансовых консультантов. Существует и такая категория клиентов, как «оптовики». Очевидно, что один человек не покупает 5-10 квартир для жилья, это инвестиции, сделанные в расчете на то, что украинский рынок недвижимости выйдет из кризиса и цены вырастут, или «парковка денег», чтобы их не потерять.

Более того, само жилье в последние пять лет трансформируется. Особенно заметным является появление «умного жилья». Если раньше можно было в ипотеку купить 2-3-комнатную квартиру, то теперь, полагаясь на личные сбережения и средства друзей и родственников, тот же покупатель может позволить себе только 13-15 кв. м. Такие квартиры часто нарушают законодательные нормы о жилищном строительстве и становятся еще одним основанием для чиновников требовать взятки. Таким образом, изменения в системе финансирования жилья идут рука об руку с физическим изменением жилищного пространства.

Также нужно обратить внимание на то, что в условиях низкого эффективного спроса на жилье застройщики пытаются снизить себестоимость квадратного метра. Учитывая рост «армии безработных» и низкий контроль условий труда, такое снижение выливается в сверхэксплуатацию строителей. Организатор профсоюза строителей описал ситуацию так:

Большинство рабочих не из Киева, они со всей Украины, из Луганска, из Тернополя. 80\% работают по контракту, который не гарантирует каких-либо трудовых прав и освобождает работодателя от [обязанности уплаты] налогов <...>, в соответствии с этим типом контракта в случае травмы работодатель не несет никаких обязанностей <...>. Часто работникам платят за объем работы, которую они выполняют, поэтому у них есть иллюзия свободы и «работа на себя». Они работают по 10-12 часов в день. Это 300 часов [в месяц], в то время как норма, согласно Трудовому кодексу, составляет 160. Также существует коллективная память о том, что строительство может быть остановлено в любое время, поэтому они работают изо всех сил <...>. «Хорошая зарплата» составляет 18 000-20 000 [600-700 евро], но зачастую зарплаты ниже. Это означает, что в час они получают 60-100 [2-3 евро].

Более того, эта работа очень опасна:

Люди умирают ежедневно. В 2016 году в жилищном комплексе «Паркові озера» рабочий был разбит плитой, он умер, и застройщик сказал, что он не работал на них, и просто дал деньги его семье. В жилищном комплексе «Яскравий» в течение четырех лет было восемь серьезных травм и одна смерть <...>. Также я получал смертельные угрозы от безопасности застройщика из-за наших попыток поговорить с рабочими рядом со строительной площадкой.

Как движущие акторы такого тренда, так и их критики не ожидали, что этот процесс будет вечным. Так и происходит последние месяцы: две большие киевские компании-застройщики «заморозили» свои проекты. Сейчас недостаточно информации, чтобы определить, насколько велик этот кризис. Более того, сложно сказать, вызван он замедлением потока инвестиций в недвижимость от вышеописанных групп покупателей или ожидаемой сменой элиты на уров- 
не города. Отвечать на эти вопросы можно будет спустя несколько месяцев после выборов мэра, которые должны состояться осенью 2020 года, но, возможно, пройдут раньше из-за давления правительства Владимира Зеленского.

\section{Выводы. Что высветил в контексте центра/периферии украинский кейс?}

Активизация (assetisation) без финансиализации и ее последствия для горожан и города. Одним из основных структурных факторов, определяющих нынешние состояние рынка недвижимости и ипотеки на Украине, является отсутствие притока капитала из-за рубежа. Последние годы ликвидность приносили доходы домохозяйств высшего среднего класса, часто в иностранной валюте. Этот ресурс весьма ограничен, и рынок недвижимости сможет избежать кризиса только в случае улучшения экономических показателей всей страны. В заявлениях новой политической элиты уже звучали обещания стимулировать финансовые потоки, которые бы вдохнули жизнь в ипотечную систему. Сложно оценить реальность этих обещаний, но независимо от того, изменится ли механизм финансирования жилья, последние пять лет показали, что активное строительство жилья не обязательно должно быть связано с глобальными финансовыми потоками. Поскольку жилищная сфера годами развивалась как сфера частных интересов, в которой жилье в первую очередь являлось финансовым активом, ситуация оттока глобального капитала от Украины спровоцировала появление локальных финансовых потоков, которые не хуже глобальных концентрируют финансы домохозяйств в руках строительных компаний и обслуживающего их административного аппарата.

Следствием этого является, во-первых, снижение доступности жилья, во-вторых, усиление ориентации на частную собственность на жилье, которая ограничивает появление доступной аренды или кооперативных форм собственности. В-третьих, происходит трансформация самого жилья. Возникают как смарт-квартиры для тех, кто пытается сохранить сбережения и доходы, пока не грянул новый кризис, так и жилищные комплексы для избранных. Наконец, городское пространство продолжает сегрегироваться с постройкой жилищных комплексов и районов для узкого круга горожан. И поскольку эти процессы продвигаются разными коалициями акторов, которые часто действуют, не договариваясь между собой, эти трансформации имеют очень хаотичный характер и редко комплексно меняют пространство. Чаще же приводят к появлениям анклавов, не вписанных в транспортную и социальную инфраструктуру города. Парадокс такого развития еще и в том, что на фоне старых стигматизированных районов, не обновляемых десятки лет, эти новые анклавы часто воспринимаются горожанами позитивно, ведь новая застройка стимулирует ожидания, что улицы будут освещаться, школа ремонтироваться, а тесную маршрутку заменит новый автобус. Не всегда эти надежды становятся реальностью.

Украинский кейс в глобальных цепочках центра/периферии. Если российский или венгерский кейс посткризисной финансиализации жилья отличается от западных тем, что бразды управления кредитным и жилищным рынком перешли в руки государственных акторов, которые восстановили локальный режим финансиализации, усилив политическую вертикаль, то украинский кейс показывает сценарий того, что происходит, если ни глобальный капитал, ни государство не готовы взять под свой контроль эту сферу. А именно, более мелкие акторы, как частные (застройщики и компании, не связанные с недвижимостью), так и государственные (высшие чиновники городского уровня), заполняют нишу и восстанавливают рынок недвижимости, опираясь не на кредитование жилья, а на сбережения и доходы конкретных групп потребителей. В то же время такой процесс становится возможным следствием периферизации экономики страны - падения реальных доходов населения и ослабления конкуренции со стороны международного капитала. В итоге место глобальных цепочек накопления через ипотечное кредитование иностранным капиталом занимают локальные цепочки накопления стоимости. И хотя масштаб режима накопления разный, логика накопления капитала через рост городов и жилищного строительства остается одинаковой.

Разрыв цепочки накопления между центральным регионом и акторами (в нашем случае австрийскими и итальянскими банками) и периферией (украинскими покупателями жилья) в ситуации глобального кризиса привел к определенной независимости последних, что может стать основой для прогрессивных изменений. Но независимость системы финансирования жилья от внешнего кредитования не гарантирует более широкого доступа к этому благу, если 
сфера находится под контролем частных акторов, тесно и неформально связанных с политической элитой. Как показывает пример Киева, скорее всего, правила игры адаптируются под местных игроков, что может привести к обновлению механизма накопления капитала, но никак не к прекращению самого процесса. То есть локальность системы финансирования жилья так же, как и глобальность, приводит к концентрации капитала. Только в этом случае основными бенефициарами являются местные элиты. И накопление капитала этими акторами никак не является более щадящим, чем до кризиса глобальными акторами. Исследовать такую смену парадигмы важно еще и потому, что большинство текстов о финансиализации как экономики в целом, так и жилья критикует именно глобальных акторов - создается впечатление, что замена их местными может улучшить ситуацию для горожан. Но это не так для Киева последних лет, что позволяет предлагать гипотезы относительно других периферий, не утративших связи с центром, но, конечно же, на основании отдельного анализа кейсов.

Такие разрывы цепочек финансиализации являются конечными этапами в процессе извлечения стоимости, для которого и вследствие которого возникают. Истощив периферию, капитал центра разрывает одну цепочку и создает или усиливает другую. В случае Украины такими «новыми» цепочками выступают кредитование международными финансовыми структурами и увеличение потока международной миграции после 2014 года. Но и «новые» цепочки не вечны, ведь у извлечения стоимости есть пределы. Таким образом, дисбалансы глобальной капиталистической системы усиливаются, не только меняя формы эксплуатации периферии центром, но и переподчиняя определенные социально-экономические сферы местным капиталам, которые хотя и функционируют по тому же принципу, что и глобальный, не включены в него полностью.

Подобные точки бифуркаций могут создавать потенциал для качественных изменений как сферы жилья, так и других общественных сфер. Но качественные изменения в плане доступности жилья, а не перетекания контроля от международных банков к застройщикам и чиновникам, возможны лишь при коллективном переосмыслении жилищных практик, финансирования жилья, распределения и использования.

\section{Источники}

Державна служба статистики України (2020). Будівництво. Режим доступа: http://www.ukrstat.gov.ua/ (дата обращения: 17.02.20).

Звіт про роботу державних та приватних нотаріусів (2020). Міністерство юстиції України. Режим доступа: https:// minjust.gov.ua/m/zvit-pro-robotu-derjavnih-ta-privatnih-notariusiv (дата обращения: 17.02.2020).

Звіт про фінансову стабільність, грудень 2017 (2017). Національний банк України. Режим доступа: https://bank. gov.ua/ua/news/all/zvit-pro-finansovu-stabilnist-gruden-2017-roku-4981 (дата обращения: 17.02.2020).

Звіт про фінансову стабільність, грудень 2019 (2019). Національний банк України. Режим доступа: https://bank. gov.ua/ua/news/all/zvit-pro-finansovu-stabilnist-gruden-2019-roku (дата обращения: 17.02.2020).

Кравчук О. (2015) Історія формування борговоі залежності Украині//Commons Journal. Режим доступа: https:// commons.com.ua/formuvannya-zalezhnosti/ (дата обращения: 17.02.2020).

Львівський IT Кластер (2020). IT Village Lviv. Режим доступа: https://itcluster.lviv.ua/projects/itvillage/ (дата обращения: 17.02.2020).

Ляшева (2019) Житло та регіональна нерівність. Чому в українських містах і селах некомфортно жити?//Commons Journal. Режим доступа: https://commons.com.ua/uk/zhitlo-ta-regionalna-nerivnist/ (дата обращения: 17.02.2020).

Офіційний курс гривні щодо іноземних валют (2020) Національний банк України. Режим доступа: https://bank. gov.ua/markets/exchangerates (дата обращения: 17.02.2020).

Статистика щодо кредитування житла (2020)//Доступ до правди. Режим доступа: https://dostup.pravda.com.ua/ request/statistika_shchodo_kriedituvanni (дата обращения: 17.02.2020).

Федорів П., Ломоносова Н. (2019) Державна житлова політика в Україні: сучасний стан та перспективи реформування. 27.11.2019//Cedos. Режим доступа: https://www.cedos.org.ua/uk/articles/derzhavna-zhytlova-polityka-v-ukraini-suchasnyi-stan-ta-perspektyvy-reformuvannia (дата обращения: 17.02.2020).

Цены на недвижимость в Украине. Киев (2020)//Domik.ua. Режим доступа: http://domik.ua/nedvizhimost/dinamika-cen.html (дата обращения: 17.02.20).

Aalbers M.B. (2016) The Financialization of Housing: A Political Economy Approach. Abingdon: Routledge. 
Arrighi G. (1994) The Long Twentieth Century: Money, Power, and the Origins of Our Times. London: Verso.

Bohle D. (2018) Mortgaging Europe's Periphery//Studies in Comparative International Development. Vol. 53. No. 2. P. 196-217.

Büdenbender M.A., Lagna A. (2019) Statecraft strategies and housing financialization at the periphery: Post-socialist trajectories in Russia and Poland. Finance and Society. Vol. 5. No. 2. P. 105-25.

Büdenbender M.A. (2017) New spaces of capital: the real estate/financial complex in Russia and Poland. Dissertation presented in partial fulfilment of the requirements for the degree of Doctor of Science (PhD): Geography. KU Leuven.

Epstein G. (2005) Financialization and the World Economy. Cheltenham: Edward Elgar Publishing.

Kamin S., DeMarco L. (2011) How did a domestic housing slump turn into a global financial crisis? Journal of International Money and Finance. Vol. 31. No. 1. P. 10-41.

Krippner G. (2004) What is financialization? University of California, Los Angeles.

Martin R. (2010) The local geographies of the financial crisis: from the housing bubble to economic recession and beyond. Journal of Economic Geography. Vol. 11. No. 4. P. 587-618.

Milesi-Ferretti G., Tille C. (2011) The great retrenchment: international capital flows during the global financial crisis. Economic Policy. Vol. 26. No. 66. P. 289-346.

Pósfai Z., Nagy E. (2017) Crisis and the reproduction of Core-Periphery relations on the Hungarian Market. European Spatial Research and Policy. Vol. 24. No. 2. P. 17-38.

Pósfai Z. (2018) Reproducing uneven development on the Hungarian housing market. Dissertation presented in partial fulfilment of the requirements for the degree of Doctor of Science (PhD): Economic and Social Geography, Marie Curie ITN, University of Szeged.

Smith N. (2008) Uneven Development: Nature, Capital and the Production of Space. Athens: The University of Georgia Press.

Sokol M. (2017). Financialisation, financial chains and uneven geographical development: Towards a research agenda//Research in International Business and Finance. Vol. 39. No. 1. P. 678-685.

Urry J. (2007) Mobilities. Cambridge: Polity Press.

Wallerstein I. (2004) World-System Analysis: An Introduction. Durham and London: Duke University Press.

Ward C., Swyngedouw E. (2018) Neoliberalisation from the Ground Up: Insurgent Capital, Regional Struggle, and the Assetisation of Land//Antipode. Vol. 50. No. 4. P. 1077-1097. 


\section{ALONA LIASHEVA \\ HOUSING BOOM IN POST-CRISIS \\ KYIV: GROWTH WITHOUT FINANCE}

Alona Liasheva, PhD, senior lecturer at Department of Sociology, Ukrainian Catholic University, Lviv, post-doctoral researcher at Forschungsstelle Osteuropa, University of Bremen, co-editor of Commons: Journal of Social Criticism; 17, Ilariona Svjentsits'koho str., off. 307, L’viv, 79000, Ukraine,

E-mail: liasheva.a@ucu.edu.ua

\section{Abstract}

This article analyses the housing boom which occurred in Kyiv between 2015 and 2019. Despite the overall economic decline, the real estate sector started booming in 2015 in big Ukrainian cities, especially in Kyiv. In order to address this issue, the research question was posed: what were the mechanisms of the housing growth in big Ukrainian cities between 2015 and 2019 in the absence of the direct foreign investment into the mortgage market. The article concludes that the growth was fueled by the extraction from such groups as workers of international companies and Ukrainian migrants working abroad. This process strengthened the positions of the local urban actors but deepened the center-periphery gap between the Ukrainian and global economies.

Keywords: housing; financialization; Kyiv; peripheral capitalism; post-Soviet cities

Citation: Liasheva A. (2019) Housing Boom in Post-Crisis Kyiv: Growth without Finance. Urban Studies and Practices, vol. 4, no 3, pp. 60-70 (in Russian). DOI: https://doi.org/10.17323/usp43201960-70

\section{References}

Aalbers M.B. (2016) The Financialization of Housing: A Political Economy Approach. Abingdon: Routledge.

Arrighi G. (1994) The Long Twentieth Century: Money, Power, and the Origins of Our Times. London: Verso.

Bohle D. (2018) Mortgaging Europe's Periphery. Studies in Comparative International Development, no 53(2), pp. 196-217.

Büdenbender M.A. \& Lagna, A. (2019) Statecraft strategies and housing financialization at the periphery: Post-socialist trajectories in Russia and Poland. Finance and Society, vol. 5, no 2, pp. 105-25.

Büdenbender M.A. (2017) New spaces of capital: the real estate/financial complex in Russia and Poland. Dissertation presented in partial fulfilment of the requirements for the degree of Doctor of Science (PhD): Geography. KU Leuven.

Derzhavna Sluzhba Statystyky Ukrainy [State Service of Statistics of Ukraine] (2020) Budivnytstvo [Construction]. Available at: http://ukrstat.gov.ua (accessed 17.02.2020). (in Ukranian)

Zeny na kvartiry v Kieve (2020) [Housing prices in Kyiv] Domik.ua. Available at: http://domik.ua/nedvizhimost/dinamika-cen.html (accessed 17.02.2020). (in Russian)
Statystyka shodo Kredytuvania Zytla - Zapyt Do Ministerstva Finansiv Ukrainy (2019) [Statistics on Mortgages - Query to Ministry of Finance of Ukraine]. Dostup do pravdy. Available at: https://dostup.pravda.com.ua/request/statistika_shchodo_kriedituvanni (accessed 17.02.2020). (in Ukranian)

Epstein G. (2005) Financialization and the World Economy. Cheltenham: Edward Elgar Publishing.

Fedoriv P., Lomonosova N. (2019) Derzhavna zhytlova polityka $\vee$ Ukraini: suchasniy stan ta perspektyvy reformuvania [State housing policy: contemporary conditions and perspectives of reforms]. Cedos. Available at: https://www.cedos.org.ua/uk/ articles/derzhavna-zhytlova-polityka-v-ukraini-suchasnyi-stan-ta-perspektyvy-reformuvannia (accessed 17.02.2020). (in Ukranian)

Kamin S., DeMarco L. (2011) How did a domestic housing slump turn into a global financial crisis? Journal of International Money and Finance, vol. 31, no 1, pp. 10-41.

Kravchuk O. (2015) Istoria formuvannia borgovoi zalezhnosti [History of formation of debt dependency of Ukraine]. Commons Journal. Available at: https://commons.com.ua/formuvannya-zalezhnosti/ (accessed 17.02.2020). (in Ukranian)

Krippner G. (2004) What is financialization? University of California, Los Angeles. 
Liasheva A. (2019) Zhytlo ta regional'na nerivnist'. Chomu v ukrainskyh mistakh i selakh nekomfortno zhyty? [Housing and regional inequality. Why are Ukrainian cities and villages not comfortable for life?] Commons Journal. Available at: https://commons.com.ua/uk/zhitlo-ta-regionalna-nerivnist/ (accessed 17.02.2020). (in Ukranian)

Lviv IT Cluster (2019) IT Village Lviv. Available at: https://itcluster.lviv.ua/projects/itvillage/ (accessed 17.02.2020). (in Ukranian)

Martin R. (2010) The local geographies of the financial crisis: from the housing bubble to economic recession and beyond. Journal of Economic Geography, vol. 11, no 4, pp. 587-618.

Milesi-Ferretti G., Tille C. (2011) The great retrenchment: international capital flows during the global financial crisis. Economic Policy, vol. 26, no 66, pp. 289-346.

Ofizijnij kurs hryvni shodo inozemnyh valut (2020) [Official rate of hryvnia to foreign currencies]. Natsionalniy Bank Ukrainy [National Bank of Ukraine] Available at: https://bank.gov.ua/markets/exchangerates (accessed 17.02.2020). (in Ukranian)

Pósfai Z., Gál Z., Nagy E. (2017) The uneven development of the housing market on the eastern periphery of Europe. Inequality and Uneven Development in the Post-Crisis World/S. Fadda, P. Tridico (eds.). London: Routledge.

Pósfai Z., Nagy E. (2017) Crisis and the reproduction of Core-Periphery relations on the Hungarian Market. European Spatial Research and Policy, vol. 24, no 2, pp. 17-38.

Pósfai Z. (2018) Reproducing uneven development on the Hungarian housing market. Dissertation presented in partial fulfilment of the requirements for the degree of Doctor of Science (PhD): Economic and Social Geography, Marie Curie ITN, University of Szeged.

Smith N. (2008) Uneven Development: Nature, Capital and the Production of Space. The University of Georgia Press.

Sokol M. (2017). Financialisation, financial chains and uneven geographical development: Towards a research agenda. Research in International Business and Finance, vol. 39, no 1, pp. 678-685.

Urry J. (2007) Mobilities. Cambridge: Polity Press.

Wallerstein I. (2004) World-System Analysis: An Introduction. Duke University Press.

Ward C., Swyngedouw E. (2018) Neoliberalisation from the Ground Up: Insurgent Capital, Regional Struggle, and the Assetisation of Land. Antipode, vol. 50, no 4, pp. 1077-1097.

Zvit pro robotu derjavnih ta privatnih notariusiv (2020) [Report on the work of public and private notaries]. Ministerstvo Yustitsii Ukrainy [Ministry of Justice of Ukraine] Available at: https://minjust.gov.ua/m/ zvit-pro-robotu-derjavnih-ta-privatnih-notariusiv (accessed 17.02.2020). (in Ukranian)

Zvit pro finansovu stabil'vist', gruden' 2017 (2017) [Report on the financial stability, December 2017]. Natsionalniy Bank Ukrainy [National Bank of Ukraine] Available at: https://bank.gov.ua/news/all/zvit-profinansovu-stabilnist-gruden-2017-roku-4981 (accessed 17.02.2020). (in Ukranian)

Zvit pro finansovu stabil'vist', gruden' 2019 (2019) [Report on the financial stability, December 2019]. Natsionalniy Bank Ukrainy [National Bank of Ukraine] Available at: https://bank.gov.ua/news/all/zvit-profinansovu-stabilnist-gruden-2019-roku (accessed 17.02.2020). (in Ukranian) 